\title{
The principal purpose test in tax treaties under BEPS 6
}

Q.W.J.C.H. Kok

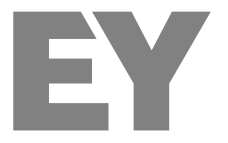

Building a better

working world 


\title{
ARTICLE
}

\section{The Principal Purpose Test in Tax Treaties under BEPS 6}

\author{
Reinout Kok*
}

\begin{abstract}
In report 6 of the BEPS action plan, Preventing the Granting of Treaty Benefits in Inappropriate Circumstances, the Organisation for Economic Co-operation and Development (OECD) proposes (amongst others) to include a principal purpose test (PPT) in tax treaties. Under this test a treaty benefit shall not be granted if it is reasonable to conclude that obtaining that benefit was one of the principal purposes of any arrangement or transaction (subjective test), unless it is established that granting that benefit in these circumstances would be in accordance with the object and purpose of the relevant provisions of the treaty (objective test). The subjective test is, from the viewpoint of the tax authorities a relatively 'easy' test. The objective test, however, can provide for some relief for taxpayers. In this article the PPT is being investigated and discussed. Especially, attention is given to the objective test. An attempt is being made to develop practical guidance to interpret the PPT, based on Dutch case law and doctrine.
\end{abstract}

\section{INTRODUCTION}

Action item 6 of the BEPS project is about 'Preventing the Granting of Treaty Benefits in Inappropriate Circumstances'. The report on this topic, that was published in October 2015 (hereafter: the report), contains various proposals. In this article one of the proposals will be investigated and discussed, namely the introduction of a so-called 'principal purpose test' (PPT) in tax treaties. This article is built up as follows. In section 2 , the meaning of the term 'treaty abuse' will be discussed. The main characteristics of the PPT will be outlined in section 3. The PPT contains a subjective test (what was the aim of the taxpayer using a certain arrangement?) and an objective test (would granting the treaty benefit defeat the 'object and purpose' of the relevant treaty provision?). These two tests will be investigated in sections 4 and 5 . This article will be concluded with a short summary in section $6 .^{1}$

\section{Treaty abUSE}

In the report a distinction is made between two ways of abuse under a tax treaty:
(1) The circumvention of provisions of the treaty itself.

(2) The circumvention of domestic law provisions.

An example of the first category is the use of conduit companies. For example, an enterprise in country A wants to invest in an enterprise in country B. However, there is no tax treaty between country A and country B. There is, however, a tax treaty between country B and country C, but application of that treaty is restricted to residents of country B and country C. The enterprise in country A tries to circumvent that restriction by setting up a conduit company in country $\mathrm{C}$, and invests via that conduit company in the enterprise in country B.

An example of the second category is trying to invoke a tax treaty to avoid application of domestic CFC-provisions or domestic thin capitalization legislation. Also not applying the domestic abuse of law doctrine (fraus legis) in an international (treaty) situation is a good example. For example, the Dutch Supreme Court has ruled that certain fact patterns that entirely took place in the Netherlands could be challenged with the abuse of law doctrine, but the same fact patterns, but now involving foreign (treaty protected) companies, could not be challenged with the abuse of law doctrine. ${ }^{2}$

\section{Notes}

Prof. dr. Reinout Kok, Erasmus University Rotterdam and EY Amsterdam.

A Dutch version of this article, Enkele aspecten van de 'principal purpose test' (written on the basis of the draft report published in 2014) was published in WFR 2015/184.

The Dutch Supreme Court has ruled in HR 15 Dec. 1993, nr. 29 296, BNB 1994/259, annotation J.C.K.W. Bartel, HR 29 Jun. 1994 , nr. 28 734, BNB 1994/294, conclusion Advocate-General Verburg, annotation P.J. Wattel and HR 15 Mar. 1995, nr. 29 531, BNB 1995/150, annotation P.J. Wattel, that fraus legis could not be 


\section{The PRINCIPAL PURPOSE TEST}

\section{I The Proposed Article X(7)}

In the report, the PPT is Article $\mathrm{X}(7)$ of the OECD Model tax convention. The proposed Article $\mathrm{X}(7)$ reads as follows:

Notwithstanding the other provisions of this Convention, a benefit under this Convention shall not be granted in respect of an item of income or capital if it is reasonable to conclude, having regard to all relevant facts and circumstances, that obtaining that benefit was one of the principal purposes of any arrangement or transaction that resulted directly or indirectly in that benefit, unless it is established that granting that benefit in these circumstances would be in accordance with the object and purpose of the relevant provisions of this Convention.

One can see two tests in order to determine whether the benefit of the treaty should be granted in a specific case. The first test is the subjective test. Was obtaining the benefit one of the principal purposes of any arrangement or transaction that resulted directly or indirectly in that benefit? If this is the case, the treaty benefit will not be granted, unless - and this is the objective test - granting that benefit would be in accordance with the object and purpose of the relevant treaty provision(s).

This is in line with the guiding principle of paragraph 9.5 of the Commentary on Article 1 of the OECD Model Convention:

A guiding principle is that the benefits of a convention should not be available where a main purpose for entering into certain transactions or arrangements was to secure a more favourable tax position and obtaining that more favourable treatment in these circumstances would be contrary to the object and purpose of the relevant provisions.

Article $\mathrm{X}(7)$ is the codification of the concept of 'fraus conventionis' that is for example well known in Dutch professional tax literature. A good definition of fraus conventionis that can be found in Dutch doctrine is:

Acting in fraudem conventionis in tax law, is when a taxpayer uses a schemeltransaction with the sole, of or at least, essential purpose to obtain the desired tax consequences on the basis of the relevant tax treaty, whilst that schemeltransaction defeats the object and purpose of the treaty. ${ }^{3}$

If one compares this definition with the proposed Article $\mathrm{X}(7)$, one can clearly recognize the similarities regarding the two tests. There is, however, a relevant difference in the subjective test. In Article $\mathrm{X}(7)$ the subjective test is met if 'one of the principal purposes' is obtaining the tax benefit, whilst under the definition of fraus conventionis, that is only the case if the sole or essential purpose' was obtaining the tax benefit. From the viewpoint of the tax authorities the subjective test under Article $\mathrm{X}(7)$ is therefore more 'easy'. This will be discussed in more detail hereunder.

Another difference is the following. Article $\mathrm{X}(7)$ is structured in a different way than the definition of fraus conventionis that was given above. In Article $\mathrm{X}(7)$, the main rule is the subjective test. If the principal purpose of an arrangement/transaction is obtaining the treaty benefit, the PPT applies. The objective test (object and purpose of a treaty) is only an exception to the main rule. Under fraus conventionis the subjective and objective test are equally important, i.e., they are not modelled as a main rule and an exception. This difference between the PPT and fraus conventionis could result in different outcomes in practice. Sometimes it might be difficult to determine what the object and purpose of a treaty and/or treaty provisions are. In such case, under the PPT, a taxpayer cannot use the objective test in order to safeguard the benefits of the treaty, because in order to invoke that exception it has to be established that granting the benefit would be in accordance with the object and purpose of the relevant treaty provision(s). In such case, applying fraus conventionis - on the contrary - would likely be difficult.

As said, the concept of fraus conventionis has been discussed in Dutch professional tax literature. It is noteworthy that the Dutch Supreme Court, so far, has not applied the concept of fraus conventionis. Reference can be made to its decision of 11 May 2006.4 In this case, the place of residence of a Dutch company was migrated to Belgium just before the company went into liquidation. Under the Belgium-Dutch treaty, this implied that the liquidation proceeds (in the hands of the shareholder) could not be taxed in the Netherlands. The Supreme Court ruled that since the treaty referred to the place of residence of a company for certain tax consequences, it could not successfully be argued (by the tax authorities) that migrating a company to Belgium to obtain those tax benefits, would be against the object and purpose of the tax treaty. It is, however, not fully clear whether the Supreme Court denied application of the concept of fraus conventionis only in this specific case, or whether the decision has a more general meaning, i.e., that fraus

\section{Notes}

applied in a treaty situation because neither from the text of the treaty itself, nor from the clarifications of the contracting states it could be derived that it was intended that fraus legis could be applied under the treaty on the arrangements at hand.

Reference is made to the annex to the conclusions of Advocate-General Van Ballegooijen in the cases 39 223, 40 450, 40451,40452 en 40453 . The annex can be found in BNB 2007/36. The translation from Dutch into English is not verbatim.

HR 12 May 2006, nr. 39 223, BNB 2007/36, conclusion Advocate-General Van Ballegooijen, annotation S. van Weeghel. See also HR 14 Jul. 2006 , nr. 42 522, BNB 2007/42, annotation S. van Weeghel. 
conventionis will never be applied by the Dutch Supreme Court. ${ }^{5}$

\subsection{Is There a Need for Article $X(7)$ ?}

It is a fair question whether Article $\mathrm{X}(7)$ does change the current practice of treaty application. Lang has argued that treaty benefits should not be granted if taxpayers act contrary to the object and purpose of a treaty. ${ }^{6}$ In his view Article $\mathrm{X}(7)$ 'does not have an independent legal significance but merely underlines the already evident need for interpretation to be based on the object and purpose of the rules. Therefore, the rule is a mere hint for the interpretation and totally expendable'. This line of reasoning might be applicable in several jurisdictions, ${ }^{7}$ but as outlined above, in the Netherlands it is not clear whether the concept of fraus conventionis can apply, and even if it could be applicable in specific cases, the Dutch Supreme Court probably will be very reluctant to apply it.

Also reference can be made to Article 31(1) of the Vienna Convention on the Law of Treaties. In that article it is stated that '[a] treaty shall be interpreted in good faith in accordance with the ordinary meaning to be given to the terms of the treaty in their context and in the light of its object and purpose'. In the author's view, this is merely a provision relating to the interpretation of terminology of a treaty, but treaty abuse is not specifically related to the interpretation of terminology.

\subsection{What is a Treaty Benefit?}

What exactly is meant by 'a benefit under this Convention'? Paragraph 7 of the draft Commentary on Article $\mathrm{X}(7)$ states that this includes all limitations (e.g., a tax reduction, exemption, deferral or refund) on taxation imposed on the State of source under Articles 6-22 of the Convention, the relief from double taxation provided by Article 23, and the protection afforded to residents and nationals of a Contracting State under Article 24 or any other similar limitations.

\section{ONE OF THE PRINCIPAL PURPOSES}

\section{I When is the Test Met?}

The tax benefit will not be granted if it is reasonable to conclude, having regard to all relevant facts and circumstances, that obtaining that benefit was one of the principal purposes of any arrangement or transaction'? The words 'reasonable to conclude' are used so that a taxpayer cannot avoid application of the PPT by merely asserting that the arrangement or transaction was not undertaken or arranged to obtain the benefits of the Convention. According to the report (paragraph 6 of the draft Commentary on Article X(7)), the determination whether an arrangement or transaction was carried out with the principal purpose of obtaining a treaty benefit requires reasonableness, suggesting that the possibility of different interpretations of the events must be objectively considered. ${ }^{10}$

The fact that has been chosen for 'one of the principal purposes' instead of e.g., for the 'sole purpose', the 'essential purpose' or 'predominant purpose', makes it relatively easy for the tax authorities to establish that the subjective test is met. ${ }^{11}$ This is of course a deliberate decision of the OECD. In the author's view, the OECD should have chosen for one of the alternative tests, because it is difficult to argue that a taxpayer is abusing a treaty if he has two equally important motives to carry out a transaction, one tax reason and one commercial reason. Nevertheless, the PPT could apply, because in this scenario the tax reason is one of the principal purposes.

\subsection{One of the Principal Purposes... of What?}

The question in the heading of this paragraph seems easy to answer. One can answer it just by referring to the wording of Article $\mathrm{X}(7)$. It is about one of the principal purposes of 'any arrangement or transaction that resulted directly or indirectly in [the treaty] benefit'.

In the report an example is given of an enterprise in country $\mathrm{R}$ that wants to open a factory abroad. Three

\section{Notes}

S. van Weeghel in his annotation under BNB 2007/42 is of the opinion that the Supreme Court has not definitely rejected the application of fraus conventionis as such. M. Tydeman-Yousef, 'Fraus conventionis, quae est?', WFR 2014/23 holds the same view. It should be noted that there is a difference between the application of frau conventionis and the application of the national concept of abuse of law (fraus legis) in treaty situations. Reference is made to s. 2 of this article.

Michael Lang, BEPS Action 6: Introducing an Antiabuse Rule in Tax Treaties, Tax Notes Intl. 655-664 (May 2014).

Reference is made to para. 9.3 of the Commentary on the OECD Model Convention: 'Other States prefer to view some abuses as being abuses of the convention itself, as opposed to abuses of domestic law. These States, however, then consider that a proper construction of tax conventions allows them to disregard abusive transactions, such as those entered into with the view to obtaining unintended benefits under the provisions of these conventions. This interpretation results from the object and purpose of tax conventions as well as the obligation to interpret them in good faith (see Article 31 of the Vienna Convention on the Law of Treaties).

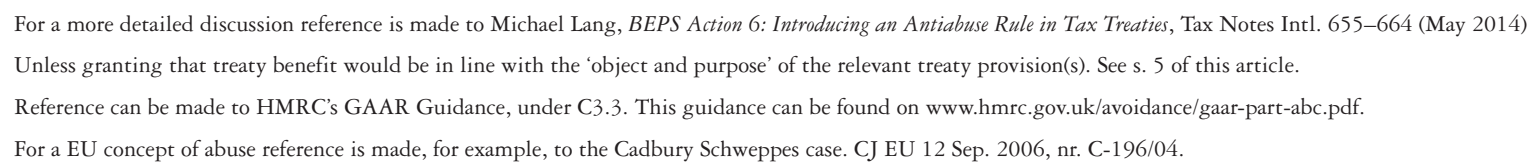


locations for that factory are being considered. It is decided to open the factory in country $S$ because that is the only country of the three countries that had been considered, that has a (beneficial) tax treaty with country R. For the subjective test of the PPT one has not to look to the motive for choosing country $\mathrm{S}$, but to the motive for building a factory. The factory is clearly not built to obtain treaty benefits, and therefore the PPT should not apply. For completeness' sake, it can also be noted that granting treaty benefits in this scenario would also be in line with the object and purpose of the treaty.

\section{ObJect ANd purpose}

\section{I Meaning}

The treaty benefit will not be denied if granting that treaty benefit would be in line with the 'object and purpose' of the relevant treaty provision(s). There is no explicit reference to the 'object and purpose' of the treaty in general. In the author's view, however, the 'object and purpose' of a treaty provision has to be interpreted in light of the 'object and purpose' of the treaty in general.

A question is whether 'object' and 'purpose' are just synonyms for each other. In literature one can distinguish two views. Buffard and Zemanek, ${ }^{12}$ for example, show that English and German writers treat the two terms as synonyms, whilst French writers give different meanings to the two terms. In practice, this seems not a very important issue. In tax literature, 'object' and 'purpose' seem to be mentioned in one breath. ${ }^{13}$ So, if there would be a difference in meaning, it does not seem to be of practical relevance for the interpretation of Article X(7).

\subsection{How to Find 'Object and Purpose'}

Where can the 'object and purpose' of a treaty or a provision of a treaty be found? The primary source for the 'object and purpose' of a treaty has to be found in the text of the treaty itself. ${ }^{14}$ The text of the treaty comprises, apart from - of course - all the treaty provisions, also the title of the treaty and the preamble to the treaty.

It is therefore important to note that the OECD proposes to amend the title of tax treaties, so that they will read as follows: ${ }^{15}$

\begin{abstract}
Convention between (State A) and (State B) for the elimination of double taxation with respect to taxes on income and on capital and the prevention of tax evasion and avoidance.
\end{abstract}

It is also proposed that the following preamble will be included in tax treaties:

(State A) and (State B), Desiring to further develop their economic relationship and to enhance their co-operation in tax matters, (i)ntending to conclude a Convention for the elimination of double taxation with respect to taxes on income and on capital without creating opportunities for non-taxation or reduced taxation through tax evasion or avoidance (including through treaty-shopping arrangements aimed at obtaining reliefs provided in this Convention for the indirect benefit of residents of third States) (b)ave agreed as follows:

How does this help us? Does this provide practical guidance? Probably not a lot, so we have to look further. 'Object and purpose' of a treaty can also be derived from the treaty provisions themselves. De Broe gives some examples: allocation of taxing rights to the two contracting states (Article 6-22 Model Convention), preventing some forms of discrimination (Article 24 Model Convention), administrative co-operation of tax authorities of the contracting states (Article 25 Model Convention), solving tax conflicts (Article 26 Model Convention), mutual assistance regarding the collection of tax claims (Article 27 Model Convention). ${ }^{16}$

Also these examples do not give a lot of practical guidance for determining whether granting a treaty benefit is in line with the 'object and purpose' of a treaty or a treaty provision. For example, the allocation of taxing rights, in other words determining which state has to step back, is intentionally limited by Article X(7) and it would therefore be incorrect to use that argument to defeat the meaning of Article X(7) if double taxation is avoided in an abusive way.

Another way of finding the 'object and purpose' of a treaty is to look at the Commentary on the Model Convention. If countries have made no relevant reservations to the Commentary on the Model Convention, one can use the Commentary as a source for determining the 'object and purpose' of a treaty or a treaty provision. ${ }^{17}$

\section{Notes}

Isabelle Buffard \& Karl Zemanek, The 'Object and Purpose' of a Treaty: An Enigma?, 3 Austrian Rev. Intl \& Eur. L., 311-343 (1998).

In his dissertation Interpretation of Tax Treaties under International Law 175 (IBFD 2004), also Frank Engelen does not distinguish between 'object' and 'purpose'.

Frank Engelen, Interpretation of Tax Treaties under International Law, 175 (IBFD 2004).

The current title is: 'Convention between (State A) and (State B) with respect to taxes on income and on capital.' A related footnote reads as follows: 'States wishing to do so may follow the widespread practice of including in the title a reference to either the avoidance of double taxation or to both the avoidance of double taxation and the prevention of fiscal evasion.'

16 L. de Broe, International Tax Planning \& Prevention of Abuse under Domestic Tax Law 288 (Tax Treaties \& EC-Law, IBFD 2008).

17 David A. Ward et al., The Interpretation of Income Tax Treaties with Particular Reference to the Commentaries on the OECD Model, 34 (IBFD 2005). 
The proposed paragraph 7 of the Commentary on Article 1 of the Model Convention ${ }^{18}$ reads as follows:

The principal purpose of double taxation conventions is to promote, by eliminating international double taxation, exchanges of goods and services, and the movement of capital and persons. As confirmed in the preamble of the Convention, it is also part of the purposes of tax conventions to prevent tax avoidance and evasion.

Assuming that the Commentary indeed is relevant for determining the 'object and purpose' of a treaty or a treaty provision, also the (draft) Commentary on Article X(7) and the various examples it contains, is therefore relevant. Those examples can give (some) practical guidance.

\subsection{Practical Guidance for Determining 'Object and Purpose'}

In this paragraph an attempt is made to give practical guidance to determine the 'object and purpose' of a tax treaty (provision). This is done on the basis of case law of the Dutch Supreme Court and Dutch professional tax literature regarding the 'object and purpose' of the Dutch domestic tax legislation. ${ }^{19}$

In the first place, one can think of the situation in which the legislator has intentionally not covered a specific situation/arrangement in the legislation. In such case, the concept of abuse of law (fraus legis) cannot be used to successfully challenge such situation/arrangement. In a treaty context it would not be easy to use this guideline, as it can be - due to lack of relevant documentation - difficult to know whether a situation/ arrangement intentionally is not covered by a treaty.

In the second place, one can think of the situation that the legislator has not introduced provisions in its domestic legislation to counter very obvious tax avoidance possibilities. ${ }^{20}$ This criterion can - to some extent - be useful in the context of tax treaties. If a specific avoidance arrangement is obvious (or already used by taxpayers) at the moment the treaty is being negotiated, contracting states should take that into account during their treaty negotiations. If they don't, that can be an argument that, apparently, they are fine with it. But, this criterion has to be used cautiously. Conduit situations, for example, are in the report on Action 6, regarded as 'abusive'. If there is no special provision in the treaty combating conduit companies, it can - in the author's view - not (automatically) successfully be argued that the use of conduit companies is in line with the 'object and purpose' of the treaty.

In the third place, one can think of the use of quantitative conditions in the treaty. If a treaty benefit is only granted if, e.g., one enterprise holds an interest of at least $25 \%$ in the other enterprise, it is in line with the 'object and purpose' of the treaty provision to grant the treaty benefit if that $25 \%$-test is met, even if the only reason for establishing that $25 \%$-shareholding is taxdriven. ${ }^{21}$ In example $\mathrm{E}$ of the draft Commentary on Article $\mathrm{X}(7)$ this approach is followed:

Example E: $R C_{0}$ is a company resident of State $R$ and, for the last 5 years, has held 24 per cent of the shares of company $S C o$, a resident of State $S$. Following the entry-into-force of a tax treaty between States $R$ and $S$ (Article 10 of which is identical to Article 10 of this Model), RCo decides to increase to 25 per cent its ownership of the shares of SCo. The facts and circumstances reveal that the decision to acquire these additional shares has been made primarily in order to obtain the benefit of the lower rate of tax provided by Article 10(2)a) of the treaty.

In that case, although one of the principal purposes for the transaction through which the additional shares are acquired is clearly to obtain the benefit of Article 10(2)a), paragraph 7 would not apply because it may be established that granting that benefit in these circumstances would be in accordance with the object and purpose of Article 10(2) a). That subparagraph uses an arbitrary threshold of 25 per cent for the purposes of determining which shareholders are entitled to the benefit of the lower rate of tax on dividends and it is consistent with this approach to grant the benefits of the subparagraph to a taxpayer who genuinely increases its participation in a company in order to satisfy this requirement.

But now let's change the example a little. Let's now assume that to obtain the treaty benefit, the shareholding of RCo in SCo is increased from $24 \%$ to $25 \%$ just one day before the dividend is being distributed. Is granting the treaty benefit (the lowered dividend withholding tax rate) in such case in line with the 'object and purpose' of the treaty? In the (current) Commentary on Article 10 of the Model Convention, it is stated that in such situation the lowered withholding tax rate should not be applied and it is given in consideration to the contracting states to include a specific provision for such situation in the treaty:

\section{Notes}

8 This is a minor revision to the current para. 7. In the report also other revisions are proposed to the Commentary on Art. 1 to better articulate the desire to combat abuse.

19 Reference is made to R.J. de Vries, Het civielrechtelijke leerstuk rechtsverwerking in de fiscale jurisprudentie van de Hoge Raad, in Kwaliteit van belastingrechtspraak. belicht, $219-229$ (liber amicorum A.O. Lubbers, Sdu Uitgevers 2013), and his annotation under Supreme Court 13 Nov. 2009, nr. 08/01904, BNB 2010/24 conclusion Advocate-General Wattel.

20 It has to be noted that it is not clear whether this criterion indeed can be used in the domestic (Dutch) context. Reference is made to the Supreme Court decision of $15 \mathrm{Mar}$ 2013, nr. 11/05609, BNB 2013/151, conclusion Advocate-General Wattel, annotation J.C. van Straaten.

21 Compare, in the Dutch domestic context, the decisions of the Supreme Court of 11 May 1988, nr. 24 918, BNB 1988/289, annotation Van Brunschot and 8 Jul. 1992, nr 28 211, annotation Van Dijck. 
'provided that this holding was not acquired primarily for the purpose of taking advantage of this provision'. In the report it is stated that to counter such abuse, a minimum holding period should be provided for in the treaty. Absent such minimum holding period, contracting states can - in the author's view - not invoke Article X(7) to deny the treaty benefit in such a case.

In the fourth place one can think of the fundamental features of a tax system. For example, in the Dutch corporate income tax act (like in almost every other country) a distinction is made between equity financing and debt financing. Making use of this difference is not against the 'object and purpose' of the tax legislation. ${ }^{22}$ This criterion can also be used in the treaty context. If taxpayers decide to finance a foreign enterprise with equity instead of with debt, because the withholding tax rate on dividends in the relevant treaty is lower than the withholding tax rate on interest, granting the treaty benefit (applying the lower dividend withholding tax rate), is in line with the 'object and purpose' of the treaty. This does not mean, however, that artificially converting a dividend into, e.g., a capital gain, cannot be challenged by the principal purpose test. ${ }^{23}$

In the author's view, taxation based on the residence of a company is a fundamental feature of (international) tax law. Migrating a company to obtain (improved) treaty protection, should therefore not be regarded as contrary to the 'object and purpose' of a treaty. Reference can be made to the decision of the Dutch Supreme Court of 12 May 2006, as mentioned in paragraph 3.1 above. ${ }^{24}$ On page 58 of the report the following situation is discussed:

The reference to 'one of the principal purposes' in paragraph 7 means that obtaining the benefit under a tax convention need not be the sole or dominant purpose of a particular arrangement or transaction. It is sufficient that at least one of the principal purposes was to obtain the benefit. For example, a person may sell a property for various reasons, but if before the sale, that person becomes a resident of one of the Contracting States and one of the principal purposes for doing so is to obtain a benefit under a tax convention, paragraph 7 could apply notwithstanding the fact that there may also be other principal purposes for changing the residence, such as facilitating the sale of the property or the re-investment of the proceeds of the alienation.

This example seems to indicate that moving residence can be challenged on the basis of Article $\mathrm{X}(7)$. This example, however, (only) deals with the motive of the taxpayer to move its residence, and does not deal with the question whether granting the treaty benefit would be in line with the 'object and purpose' of the treaty. It is noted, for completeness' sake, that in the report it is proposed to determine the treaty residence of a company no longer on the basis of the tie-breaker rule (where is the effective management situated), but on the basis of a mutual agreement procedure. In light also of the above, it can be argued that if countries chose to stick to the traditional tie-breaker rule, they cannot successfully challenge the move of residence of a company by invoking Article X(7).

To conclude this paragraph, hereunder also some arguments will be discussed that (probably) cannot successfully be invoked to argue that granting treaty benefits would be in line with the 'object and purpose' of the treaty (provision).

As already outlined in paragraph 5.2 one cannot simply use the argument that the 'object and purpose' of a treaty (provision) is to determine that a country cannot effectuate its taxing rights (it has to step back). This argument would defeat the entire meaning of Article X(7). The same applies to the argument that treaties want to stimulate the global trade and lowering the tax burden (even by using abusive arrangements) would be positive for the global trade.

Also the argument that contracting states forfeit their right to invoke Article $\mathrm{X}(7)$ if they do not renegotiate their treaty if a new form of abuse is detected, is weak. Treaty negotiations are slow and time consuming and it cannot be expected from the contracting states that each time a new form of abuse pops up, the treaty is (promptly) renegotiated. ${ }^{25}$ The same applies if the abusive arrangement/transaction is not yet applied in practice, but on a theoretical level is being described in professional tax literature after the treaty entered into force. ${ }^{26}$

Also the fact that a limitation on benefits clause is included in a treaty does not mean that Article $\mathrm{X}(7)$ can no longer be applied. The argument would be that if one meets the (stringent) limitation on benefits conditions, which also have the avoidance of abuse as a background, getting treaty benefits would be in line with the 'object and purpose' of the treaty. In other words, the argument would be that the 'object and purpose' of the treaty is to grant treaty benefits to companies that meet the (stringent) limitation on benefit provisions. This line of argumentation is incorrect. Reference is made to the following paragraph of the draft Commentary on Article $\mathrm{X}(7)$ in the report:

\section{Notes}

Reference is made to the decision of the Supreme Court of 7 Feb. 2014, nr. 12/03540, BNB 2014/79, conclusion Advocate-General Wattel, annotation R.J. de Vries

See s. 54 of the report.

Decision of 12 May 2006, nr. 39 223, BNB 2007/36, conclusion Advocate-General Van Ballegooijen, annotation S. van Weeghel.

Reference is made to the decision (under Dutch domestic tax legislation) of the Supreme Court of 10 Jul. 2009, nr. 43 363, BNB 2009/237, annotation J.C. van Straaten.

Reference is made to the decision (under Dutch domestic legislation) of the Supreme Court of 13 Nov. 2009, nr. 08/01904, BNB 2010/24, conclusion Advocate-General Wattel, annotation R.J. de Vries. 
Conversely, the fact that a person is entitled to benefits under paragraphs 1 to 6 does not mean that these benefits cannot be denied under paragraph 7. Paragraphs 1 to 6 are rules that focus primarily on the legal nature, ownership in, and general activities of, residents of a Contracting State. As illustrated by the example in the next paragraph, these rules do not imply that a transaction or arrangement entered into by such a resident cannot constitute an improper use of a treaty provision. ${ }^{27}$

The same applies to stringent beneficial ownership provisions. One cannot successfully argue that meeting the (stringent) beneficial ownership provision implies that getting treaty benefits would be in line with the object and purpose of the treaty. Reference is made to paragraph 12.5 of the (current) Commentary on Article 10 of the Model Convention:

The fact that the recipient of a dividend is considered to be the beneficial owner of that dividend does not mean, however, that the limitation of tax provided for by paragraph 2 must automatically be granted. This limitation of tax should not be granted in cases of abuse of this provision (see also paragraphs 17 and 22 below). As explained in the section on 'Improper use of the Convention' in the Commentary on Article 1, there are many ways of addressing conduit company and, more generally, treaty shopping situations. These include specific anti-abuse provisions in treaties, general anti-abuse rules and substance-over-form or economic substance approaches. Whilst the concept of 'beneficial owner' deals with some forms of tax avoidance (i.e. those involving the interposition of a recipient who is obliged to pass on the dividend to someone else), it does not deal with other cases of treaty shopping and must not, therefore, be considered as restricting in any way the application of other approaches to addressing such cases.
It is noted that the points of view of the OECD (regarding the concurrence of the PPT on one hand and the LOB provision and the beneficial ownership provision on the other hand) as mentioned above are in line with decisions of the Dutch Supreme Court on applying the concept of abuse of law (fraus legis) in the domestic context in situations where the legislator had introduced detailed anti-abuse legislation. Notwithstanding the detailed anti-abuse legislation, it turned out to be possible that situations that fell outside (the verbatim of) the detailed legislation, could be successfully challenged with the concept of abuse of law. ${ }^{28}$

\section{Conclusion}

Introducing the principal purpose test in treaties means that the concept of 'fraus conventionis' is introduced in treaties. A lot of treaties, of course, do already have a (kind of) PPT, but the use of a PPT will become more widespread. Therefore it is important to try to (better) understand its meaning and practical implications. It follows from the above that, from the position of the tax authorities, the subjective test of the PPT is a relatively 'easy' test, if one compares it with, e.g., an essential purpose test or dominant purpose test. The objective test can provide some relief for taxpayers.

The interpretation of the various elements in the PPT might not be easy in practice. Although the draft Commentary on Article X(7) gives examples of the scope of Article X(7), especially the 'object and purpose' test is not easy to interpret. In this article, an attempt has been made to develop practical guidance to interpret Article $\mathrm{X}(7)$, based on Dutch case law and doctrine.

\section{Notes}


Ernst \& Young LLP

Accountancy | Belastingen |

Transacties | Advies

\section{Over Ernst \& Young}

Ernst \& Young is wereldwijd toonaangevend op het gebied van accountancy, belastingen, transacties en advies. Onze 135.000 mensen delen wereldwijd dezelfde waarden en staan voor kwaliteit. Wij maken het verschil door onze mensen, onze cliënten en de samenleving te helpen hun mogelijkheden optimaal te benutten.

Voor meer informatie: www.ey.nl

is verbonden aan

Ernst \& Young Belastingadviseurs LLP

\section{Tel: $\quad 088-4078505$}

E-mail: reinout.kok@nl.ey.com

Verschenen in:

Intertax $2016 \mathrm{nr} .5$

May 2016. - p. 406-412,

een uitgave van

Kluwer Law International te Den Haag

\section{Disclaimer}

Dit bericht is met grote zorgvuldigheid samengesteld. Voor mogelijke onjuistheid en/of onvolledigheid van de hierin verstrekte informatie aanvaardt Ernst \& Young geen aansprakelijkheid, evenmin kunnen aan de inhoud van dit bericht rechten worden ontleend.

(c) Ernst \& Young 2016

\section{INTERTAX}

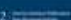

2

$19=$

31

56

$4=$

$83=$

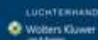

